\title{
Effect of different price indices on linkage between real GDP growth and real minimum wage growth in Turkey
}

\author{
Onur Sunal a*, Özge Sezgin Alpb \\ a Başkent University, Department of Banking and Finance, Bağlıca Kampüsü, Ankara-Turkey \\ b Başkent University, Department of Accounting and Financial Management, Bağlıca Kampüsü, Ankara-Turkey \\ *Corresponding author's email address: osunal@baskent.edu.tr
}

\begin{abstract}
A R T I C L E I N F O
Received: 16-02-2016

Accepted: 28-02-2016

Keywords:

Economic growth;

minimum wages;

price indices;

Turkey.
\end{abstract}

Available online: 02-03-2016

JEL Classification:

C43; J31; 040.

(C) 2016 The Authors. This is an open access article under the terms of the Creative Commons Attribution License 4.0, which allows use, distribution and reproduction in any medium, provided the original work is properly cited.

\begin{abstract}
A B S T R A C T
The accuracy of Turkish CPI as a price deflator is questionable especially when it comes to calculating real minimum wages. In this study we investigate the effect of different price indices on the relation between real GDP growth rates and real minimum wage growth rates by using a Granger causality analysis framework using VAR based granger causality tests. Result reveals that there is no causality between real minimu wage growth rates and real GDP growth rates in both directions. We also find a biderectional Granger causality between nominal minimum wage growth rates and COLI (an alternative price indice) growth rates. The results also showed that in line with our assumptions when an alternative deflator is used, the causality relations significantly differes.
\end{abstract}

DOI: http://dx.doi.org/10.18533/jefs.v4i1.213

\subsection{Introduction}

Minimum wages are important not only because their current or future expected values have impact on equilibrium market employment rates, price (nominal wage) inflation rates or growth rates. In a country like Turkey, minimum wage earners represent $41 \%$ of formal sector employees according to Turkish Social Security Agency statistics (2012). Moreover when employees who have earnings very close to minimum wage rates (within the range of maximum $10 \%$ more of minimum wages) are taken into account this ratio increases to $58 \%$. This roughly means that, more than $50 \%$ of the formal sector workers live on minimum wages as the numbers reveal. In our previous study (Sunal and Sezgin Alp, 2015) using Granger causality framework we found a oneway causality from real GDP growth rates to real minimum wage growth rates. Nevertheless the calculations made and the results obtained heavily depend on the deflator selected. In our previous study we used TUIK's (Turkish National Statistics Agency) price deflators to calculate real minimum wages. Therefore we assume that if other deflators were to be used the outcomes might have been significantly different. Besides we also assume that TUIK's deflators are underestimating the true change in price levels as a result of basket selection and item weighing. In that manner it can be observed that the accuracy of price deflators has long been debated internationally after The Stigler Committee Report (1961) and The Boskin Report (1996). In line with these debates in many studies (Costa, 2000; Hamilton, 1998; Barrett and Brzozowski, 2010; Beatty and Larsen, 2005) the official CPIs were found to be overestimating the true change in prices. Nevertheless in some other studies (Murphy and Garvey, 2004; Murphy and Garvey, 2005; Heineke, 1979; Moosa, 1997) it has been revealed that the official CPIs were an underestimate of the real change in price levels. 
In that respect the accuracy of Turkish CPI constructed by TUIK (Turkish National Statistics Agency) as a measure of change in the cost of living especially for minimum wage earners seems questionable. The main reason is that TUIK constructs the CPI basket and determines the weight of items in this basket by taking a representative household into account. As declared by TUIK, CPI basket is constructed so as to represent all the individuals in Turkey. Therefore the representative household or the individual is merely a weighted average of the rich and the poor households. Though according to Engel's law households are considered to be equally well-off if their food expenditure/budget ratios are equal to each other. In other words as income falls the share of expenditure devoted to food rises. Therefore COLI calculated by Istanbul Chamber of Commerce (ITO) seems an important alternative to CPI. Although the same representative household approach is taken into account the share of food and housing expenditures are substantially higher in COLI basket.

We assume that the use of such a different price index (ITO's Cost of Living Index) might have some important implications. When the change in real GDPs (155\%) and real minimum wages (\%167) during 1988-2012 period are calculated and compared by using CPI $(1994=100)$ deflators a one way causality (Turkish GDPs $\rightarrow$ Turkish Real Minimum Wages) was observed in our previous study (Sunal and Sezgin Alp, 2015). In fact when CPI is used as a price deflator the overall rise in real minimum wages is even higher than the overall rise in real GDP levels during 1988-2012 period and moreover GDP growths cause real minimum wage growths. Nevertheless contrasting with this finding if real minimum wages were to be deflated by ITO's COLI the overall rise in real minimum wage rates (76\%) is not even half of the overall rise in real GDP growth rates (\%155) for the same period. Therefore the main objective of this study is to determine whether real GDPs still granger cause real wages if real wages were to be calculated by using COLI deflators. This objective is important as the outlined relationship above seems to create a legitimate ground for the governments to justify their minimum wage determination policy when the official TUIK CPIs are used. In fact in the presence of a different price index if the outcomes will be different (no causality and a lower minimum wage growth rate) then the minimum wage determination policy and the process might somehow be altered. Also another important fact is that when the current real minimum wage rate is taken as a steady state level only the inflationary concerns and expectations shape the nominal minimum wage rate determination process which is practically controlled by the government although the workers are represented by the biggest labor union confederation during the process where a collective bargaining procedure is used as a tool for progression. Moreover, we also aim to reveal the relationship between nominal minimum wage rate growths and COLI growth rates (COLI price inflation rates). Hence a two way Granger causality between these variables would indicate that the minimum wage determination process is inflation driven rather than welfare oriented.

We also aim to contribute to the relevant international and national literature in a few ways. It can be observed that the relationship between minimum wages and employment has been investigated in numerous studies (Stigler, 1946; Deere, Murphy, and Welch 1995; Prasch, 1996; Dickens, Machin and Manning, 1999; Rama, 2001; Irmen and Wigger, 2002; Neumark and Wascher, 2006; Kaufman, 2010) when international literature is reviewed. In these studies regardless of the sign of the effect -whether minimum wages have a positive or a negative effect on employment or growth rates- the direction of the relationship investigated has always been from minimum wages to employment or growth rates. In other words the effects of economic growth on minimum wages were not principally studied as the employment effects of minimum wages were considered to be at the center of the debate. Also the minimum wage earners consist of only a small minority of the employed in highly industrialized western economies. Therefore the effect of economic growth on minimum wages might not be considered as a primary issue. Although for a country like Turkey the relationship is very important as $41 \%$ of employed are receiving minimum wages. Moreover these minimum wage earners claim to have a fair share from the rises in national income growths. As a result we also would like to make a contribution to the relevant field by emphasizing the effect of economic growth on real minimum wages.

\subsection{Data}

The annual growth rates of Turkish Real GDP, Turkish Real Minimum Wages, COLI and Turkish Nominal Minimum Wages during 1988-2012 period are used in this study. Annual Real GDP growth rates are measured by using TUIK's data (1987 reference base year series are used for calculating real GDP growths for 1988-2006 period and 1998 reference base year series are used for calculating 2007-2012 period). COLI price deflators are calculated by using ITO's COLI data $(1968=100)$. Then real minimum wages are obtained by using COLI price deflators and their annual growth rates are calculated respectively. 
Table 1: Annual Inflation Rates in Turkey calculated by using COLI and CPI (1998-2012) ${ }^{1}$ COLI Inflation Rates \% $(1968=100)$

\begin{tabular}{rrr}
\hline & COLI Inflation Rates \% $1968=100)$ & CPI Inflation Rates \% $(1994=100)$ \\
\hline 1988 & 66,22 & 61,57 \\
1989 & 73,31 & 64,28 \\
1990 & 63,22 & 60,41 \\
1991 & 67,86 & 71,14 \\
1992 & 75,18 & 65,97 \\
1993 & 85,83 & 71,08 \\
1994 & 135,74 & 125,49 \\
1995 & 74,75 & 76,05 \\
1996 & 87,95 & 79,76 \\
1997 & 108,03 & 99,09 \\
1998 & 71,26 & 69,73 \\
1999 & 59,87 & 68,79 \\
2000 & 41,69 & 39,03 \\
2001 & 55,26 & 68,53 \\
2002 & 29,41 & 29,75 \\
2003 & 21,75 & 12,71 \\
2004 & 7,44 & 9,35 \\
2005 & 11,59 & 7,72 \\
2006 & 10,37 & 9,65 \\
2007 & 12,01 & 8,39 \\
2008 & 12,73 & 10,06 \\
2009 & 6,92 & 6,53 \\
2010 & 8,87 & 6,40 \\
2011 & 8,19 & 10,45 \\
2012 & 7,98 & 6,16
\end{tabular}

Consistent with our expectations, Table 1 reveals that inflation rates calculated by COLI and CPI largely differ from each other. When the period in this study (1988-2012) is taken into consideration the prices rose 8922 and 5907 times respectively with COLI and CPI indexes. Turkey has experienced very high levels of chronic inflation rates for a very long period. Moreover the aggregate effect in the last 25 year period is so high that it can only be stated with numbers in thousands. And as a matter of fact even the difference in between the change in general price levels in between COLI and CPI is 0.338 fold during the 1988-2012 period. In other words the CPI underestimates the rise in prices by 33.8\% when compared to COLI during 1988-2012. This number might lead to an important misperception as it sounds small though the effect it creates when calculating real wages are enormous.

During 1988-2012 period when real wages are calculated by COLI deflators, real wages rose by $76.9 \%$. Alternatively when real wages are calculated by CPI deflators, real wages rose by $167.2 \%$. The purchasing power or the welfare of minimum wage earners not even doubles (the rise is only 0.76 fold) when determined by COLI and not surprisingly it nearly triples (the rise is 1.67 fold) when determined by CPI during the same period.

Table 2: Consumer Baskets Used in calculating CPI and COLI in Turkey (2014)

\begin{tabular}{|c|c|c|c|}
\hline \multicolumn{2}{|c|}{ Cost of Living Index (COLI) $1968=100$} & \multicolumn{2}{|c|}{ CPI (Consumer Price Index) 1994=100 } \\
\hline COLI Basket & Weights (\%) & CPI Basket & Weights (\%) \\
\hline Food Expenditures & 42,49 & Food Expenditures & 29,74 \\
\hline Housing Expenditures & 20,72 & Housing Expenditures & 16,41 \\
\hline Furniture and Household Goods & 8 & Furniture and Household Goods & 7,52 \\
\hline Clothing Expenditures & 12,78 & Clothing Expenditures & 7,17 \\
\hline Health and Personal Care Expenditures & 2,82 & Health and Personal Care Expenditures & 2,44 \\
\hline Transportation Expenditures & 5,95 & Transportation and Communication Exp. & 20,24 \\
\hline Education, Culture and Entertainment & 4,44 & Education, Culture and Entertainment & 5,62 \\
\hline Other & 2,80 & Other & 10,86 \\
\hline
\end{tabular}

As presented in Table 2, Food and Housing Expenditures consist of $63.21 \%$ of consumer basket in COLI and $46.15 \%$ of consumer basket in CPI. There is a very high significant difference in between these two price index series when it comes to weighing food and housing expenditures. Yet alone the difference in between the weights assigned to only food expenditures is $12.75 \%$ (42.49\% and $29.74 \%)$. Hence as a result the annual inflation rates differ from each other as can be seen from Table 1. Also consistent with our expectations when a basket with a higher food expenditure ratio is used CPI tends to underestimate the rises in cost of living conditions by $33.8 \%$.

\footnotetext{
${ }^{1}$ The data used for constructing monthly CPI values represent prices of items obtained from 26 different regions from all over Turkey where the monthly reference price of the specific item is a population weighed average price. The data used for constructing COLI values represent prices of items obtained from 15 different districts of İstanbul (Though the population of İstanbul is officially $18.50 \%$ of the whole national population). Moreover, the prices of 432 and 242 items are collected for CPI and COLI respectively. Both indexes are calculated by using the same Laspeyres' formula.
} 


\subsection{Methodology}

In this paper, we used causality analysis proposed by Granger (1969) to investigate the relationships between real GDP growth rates and real minimum wage growth rates and between COLI growth rates and nominal minimum wage growth rates. In Granger causality framework the definition of the relation is based on the stationarity hypothesis of the series. Therefore stationarity tests are the first step analysis of Granger causality framework. In relevant literature there are different types of stationarity tests also known as unit root tests. In this study, Augmented Dickey Fuller (ADF) test, a unit root test which is introduced by Dickey and Fuller (1979) is used. In general if the series are stationary after determining the optimal lag lengths, VAR model based Granger causality tests might be conducted. Conversely, if the series are non-stationary the second step involves cointegration analysis which displays the long run co-movement of variables. In this study, a Vector Autoregressive (VAR) based co-integration test introduced by Johansen and Jeselius (1990) is used. This test is also known as Johansen and Jeselius co-integration test. As it is well known VAR model includes lagged terms of all variables and moreover lag length plays a crucial role for correct modeling. In addition, Johansen and Jeselius co-integration test is sensitive to lag lengths. The determination of the optimal leg lengths requires the use of different information criteria. The further step involves the application of the co-integration tests. If no co-integration relations are observed then Granger causality tests can be applied directly. However, if there is co-integration; Vector Error Correction Model (VECM) will be more appropriate to use as VECM not only includes the lagged terms of the variables but also includes the first differences of the variables in separate equations. VECM shows both short-run and long-run relationships at the same time. Finally VECM based Granger Causality Tests might be conducted to find out both the presence and the direction of the causality relationships in between relevant series or variables. This explained methodological procedure was used step by step in this paper to investigate the relationships in between the relevant variables discussed earlier.

\subsection{ADF Unit Root Test}

As mentioned above, the first step in Granger causality analysis is the verification of the stationarity of the time series used in the study. In time series modelling, stationarity is a very important concept as this is an essential condition for both obtaining valid inferences and for determining the orders of integration for co-integration analysis.

In $\mathrm{ADF}$ approach to test the stationary of time series variable $\mathrm{x}$ the following regression equation is used,

$$
\Delta x_{t}=\beta_{0}+\lambda t+\psi x_{t-1}+\sum_{i=1}^{p} \alpha_{i} \Delta x_{t-i}+\varepsilon_{t}
$$

In equation $1, \Delta$ is the difference operator, $\beta_{0}$ is the constant and $t$ is the trend term. If the estimated coefficient $\psi$ is equal to zero, the equation is said to be in the form of first differences $I(1)$ and contains a unit root. If the calculated ADF statistic is higher than McKinnon's critical value then the null hypothesis cannot be rejected and it may be concluded that the considered variable is non-stationary.

\subsection{Johansen-Jeselius co-Integration test}

When time series are non-stationary the second step of causality analysis involves co-integration analysis. Cointegration analysis is needed to identify the long-run relationships between two or more variables and to overcome the risk of obtaining invalid inferences. A set of variables are defined as co-integrated if a linear combination of them is stationary after the series are differenced.

Johansen-Jeselius co-integration test is a Vector Autoregressive (VAR) based co-integration test. The separate equations of each variable in VAR include the lagged terms of all variables. For a k variable VAR model with p-lags, the specification is:

$$
x_{t}=\mathrm{A}_{0}+\mathrm{B}_{1} x_{t-1}+\mathrm{B}_{2} x_{t-2}+\ldots+\mathrm{B}_{p} x_{t-p}+\mathrm{E}_{t}
$$

Where, $\mathrm{A}_{0}$ is the $k x 1$ vector of constants, $\mathrm{B}_{j}$ is the $k x k$ matrix of coefficients and $\mathrm{E}_{t}$ is the $k x 1$ vector of residuals.

The transformation of equation 2 into a VECM model as below is needed if Johansen and Jeselius co-integration test is going to be used: 
$\Delta x_{t}=\mathrm{A}_{0}+\Gamma_{1} \Delta x_{t-1}+\Gamma_{2} \Delta x_{t-2}+\ldots+\Gamma_{p-1} \Delta x_{t-p+1}+\Pi x_{t-k}+\mathrm{E}_{t}$

Here, $\Pi=\sum_{j=1}^{p} \mathrm{~B}_{j}-I_{k}$ and $\Gamma_{i}=\sum_{j=1}^{i} \mathrm{~B}_{j}-I_{k}, I_{k}$ is the $k x k$ identity matrix, $\Gamma_{i}$ represents the coefficient vector of short-run dynamics, $\Pi$ is the long-run impact matrix.

The Johansen and Jeselius co-integration test has two statistics obtained from the Eigen values of $\Pi$ matrix. The first one is the Trace Test statistic.

$$
\lambda_{\text {trace }}(r)=-T \sum_{i=r+1}^{k} \ln \left(1-\hat{\lambda}_{i}\right)
$$

The second one is the Maximum Eigen Value test statistic.

$$
\lambda_{\max }(r, r+1)=-T \ln \left(1-\hat{\lambda}_{r+1}\right)
$$

Where, $r$ is the number of co integrated vectors ranges from 0 to $\mathrm{n}-1, \hat{\lambda}_{i}$ is the estimated value for $\mathrm{i}^{\text {th }}$ ordered Eigen value of $\Pi$ matrix and $T$ is the number of usable observations.

The trace test is equal to the maximum likelihood ratio test for $r$ co-integrated vectors against the alternative $n$ vectors. It is a joint test where the null hypothesis is that the number of co - integrated vectors are less than or equal to $r$.

The maximum eigenvalue test is based on the null hypothesis that the number of co-integrating vectors is $r$ against the alternative of $r+1$ vectors. It is conducted as separate tests on Eigen values.

\subsection{Granger causality test}

Granger causality test is developed by Granger (1969) to find out whether the values of one particular time series are useful in predicting another one. If $x_{t}$ and $y_{t}$ are two stationary time series. The causal model between them is:

$$
\begin{aligned}
& x_{t}=\alpha_{1}+\sum_{j=1}^{p} a_{j} x_{t-j}+\sum_{j=1}^{p} b_{j} y_{t-j}+\varepsilon_{1 t} \\
& y_{t}=\alpha_{2}+\sum_{j=1}^{p} c_{j} x_{t-j}+\sum_{j=1}^{p} d_{j} y_{t-j}+\varepsilon_{2 t}
\end{aligned}
$$

In Granger causality framework the null hypothesis includes the non-causality and can be tested with $\mathrm{F}$ statistics. Here, if $b_{j}$ is not equal to zero $y_{t}$ is causing $x_{t}$ and if $c_{j}$ is not equal to zero than $x_{t}$ is causing $y_{t}$.

In Granger causality the series are assumed to be stationary but in reality some macroeconomic series are nonstationary. Nevertheless Engle and Granger (1987) provided a new method to overcome this problem. They revealed that if independent series $x_{t}$ and $y_{t}$ are non-stationary and are integrated of the same order $\mathrm{d}$ then the linear combination $z_{t}=x_{t}-a y_{t}$ is integrated of order $\mathrm{d}-\mathrm{b}$. When this is the case the series are said to be cointegrated of order $(d, b)$. The Granger Representation Theorem given in their paper states that if a set of variables are co-integrated, a valid error correction representation of these series exist. Hence there is no need to take the differences of these series. One known implication of this result is that if $x_{t}$ and $y_{t}$ is co-integrated of order $(1,1)$ then there exists a Granger causality relationship at least in one direction. The causality model for the cointegrated series is as follows:

$$
\begin{aligned}
& \Delta x_{t}=\alpha_{1}+\beta_{1} \pi_{t-1}+\sum_{j=1}^{p-1} a_{j} \Delta x_{t-j}+\sum_{j=1}^{p-1} b_{j} \Delta y_{t-j}+\varepsilon_{1 t} \\
& \Delta y_{t}=\alpha_{2}+\beta_{2} \pi_{t-1}+\sum_{j=1}^{p-1} c_{j} \Delta x_{t-j}+\sum_{j=1}^{p-1} d_{j} \Delta y_{t-j}+\varepsilon_{2 t}
\end{aligned}
$$


Table 3: ADF Stationarity Test Results of Real GDP Growth Rate Series and Real Minimum Wage Growth Series on Their Own Levels

\begin{tabular}{|c|c|c|c|c|c|c|}
\hline & \multirow{2}{*}{\multicolumn{5}{|c|}{ 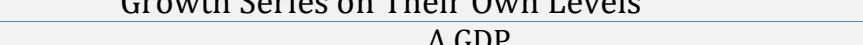 }} & \multirow{2}{*}{$\Delta$ Real Wage } \\
\hline & & & & & & \\
\hline & none & int. & int./trend & none & int. & int./trend \\
\hline ADF Test Statistics & -5.898 & -5.774 & -3.701 & -4.797 & -4.689 & -4.641 \\
\hline P-Value & 0.0001 & 0.0005 & 0.0007 & 0.0008 & 0.0053 & 0.0001 \\
\hline & $\Delta$ Real & $\begin{array}{l}\text { DP: Annu } \\
\text { : Annual I }\end{array}$ & $\begin{array}{l}\text { of change of } \\
\text { hange of Re }\end{array}$ & $\begin{array}{l}\text { GDP } \\
\text { imum W }\end{array}$ & & \\
\hline
\end{tabular}

Table 4: ADF Stationarity Test Results of COLI Growth Rate Series and Nominal Minimum Wage Growth Series on Their Own Level

\begin{tabular}{lcccrrr} 
& \multicolumn{3}{c}{ Growth Series on Their OWn Level } \\
& none & int. & int./trend & none & int. & int./trend \\
\hline ADF Test Statistics & -1.191 & -2.786 & -1.179 & -1.426 & -3.232 & -1.062 \\
P-Value & 0.6609 & 0.2153 & 0.2109 & 0.5527 & 0.1021 & 0.2516 \\
\hline \multicolumn{7}{c}{$\Delta$ COLI: Annual Rate of change of COLI (COST of Living Index) } \\
& \multicolumn{4}{c}{ Nominal Wage: Annual Rate of Change of Nominal Minimum Wages } \\
\hline
\end{tabular}

\subsection{Results and discussion}

As explained above initally the stationarity of the series were investigated by using ADF tests. Table 3 and 4 shows the ADF test results for all of the variables including the intercept, intercept and trend and none of the components. It can be seen that the null hypothesis that the series are non-stationary was rejected for real GDP growth rate series and real minimum wage growth rate series. However it can be concluded that both COLI growth rates and nominal minimum wage growth rate series were non-stationary at $5 \%$ significance levels.

As COLI growth rate series and nominal minimum wage growth rate series were found to be non-stationary, as a conventional next step the stationarity of these series on their first difference levels were examined. Therefore, ADF test was applied to COLI growth rate and nominal minimum wage growth rate series on their first difference levels. Table 5 shows the ADF stationary test results for COLI growth rate and nominal minimum wage growth rate variables on their first differences. The results showed that these series were stationary at their first difference levels. Then it was concluded that these series' integrating order was 1 . These results indicated cointegration between these variables and therefore co-integration order of the model should be selected as 1 .

Table 5: ADF stationarity test results for COLI and nominal minimum wage variables on first differences

\begin{tabular}{lrrrrrr}
\hline & \multicolumn{3}{c}{$\Delta$ COLI } & \multicolumn{2}{r}{$\Delta$ Nominal Wage } \\
\cline { 2 - 7 } & none & int. & int./trend & None & int. & int./trend \\
\hline ADF Test & -4.4849 & -1.1242 & -6.7806 & -7.0257 & -6.9263 & -7.0528 \\
$\begin{array}{l}\text { Statistics } \\
\text { P-Value }\end{array}$ & 0.0020 & 0.8974 & 0.0000 & 0.0000 & 0.0000 & 0.0000 \\
\hline
\end{tabular}

As real minimum wage growth rate series and real GDP growth rate series were stationary on their own levels VAR model based causality tests were conducted after determining the optimal lag lenghts. The information criteria results for the optimal lag lengths to analyze the relationships between real GDP growth rates and real minimum wage growth rates are given in Table 6 . As seen from Table 6 the optimal lag length for this model was one.

\begin{tabular}{|c|c|c|c|c|c|c|}
\hline \multicolumn{7}{|c|}{$\begin{array}{c}\text { Table 6: Optimal Lag Length Criteria for Real GDP Growth Rates and Real Minimum Wage Growth Rates } \\
\text { Model }\end{array}$} \\
\hline Lag & $\log \mathrm{L}$ & LR & FPE & AIC & SC & $\mathrm{HQ}$ \\
\hline 0 & -1.408 .704 & NA & 5494.238 & 14.28704 & 14.38662 & 14.30648 \\
\hline 1 & -1.385 .376 & $3.965744 *$ & 6519.617* & $14.45376^{*}$ & $14.75248^{*}$ & $14.51208^{*}$ \\
\hline 2 & -1.378 .324 & 1.057867 & 9220.051 & 14.78324 & 15.28110 & 14.88043 \\
\hline 3 & -1.367 .002 & 1.471873 & 12785.14 & 15.07002 & 15.76703 & 15.20608 \\
\hline 4 & -1.352 .271 & 1.620428 & 17778.64 & 15.32271 & 16.21887 & 15.49765 \\
\hline 5 & -1.283 .218 & 6.214716 & 15213.73 & 15.03218 & 16.12749 & 15.24600 \\
\hline $\begin{array}{l}\text { * indi } \\
\text { LR: S } \\
\text { FPE: } \\
\text { AIC: } \\
\text { SC: S }\end{array}$ & $\begin{array}{l}\mathrm{d} \text { by the criter } \\
\text { test statistic } \\
\text { terion } \\
\text { iterion }\end{array}$ & $\begin{array}{l}\text { n } \\
\text { ch test at } 5 \% \text { le }\end{array}$ & & & & \\
\hline
\end{tabular}


Table 7: Granger causality test results between real GDP growth rates and real minimum wage growth rates

\begin{tabular}{lrrc} 
Null Hypothesis: & Obs & F-Statistic & Prob. \\
\hline RWAGES does not Granger Cause GDP & 24 & 2.55386 & 0.1250 \\
GDP does not Granger Cause RWAGES & & 1.22437 & 0.2810 \\
\hline
\end{tabular}

As the optimal lag lenght of the real minimum wage growth rate and real GDP growth rate series model was calculated as one VAR based Granger causality tests were conducted. Table 7 shows Granger causality relations between real GDP growth rates and real minimum wage growth rates. It can be seen from Table 7 that neither variable granger caused the other one. In other words there was not a significant causal relationship between real GDP growth rate series and real minimum wage growth rate series in both directions.

Table 8: Optimal Lag Length Criteria for COLI growth rates and nominal minimum wage

\begin{tabular}{lrrrrrr}
\multicolumn{7}{c}{ growth rates model } \\
\hline Lag & LogL & LR & FPE & AIC & SC & HQ \\
0 & -1.908 .706 & NA & 815432.2 & 19.28706 & 19.38663 & 19.30650 \\
1 & -1.740 .314 & 28.62667 & 226827.9 & 18.00314 & 18.30186 & 18.06145 \\
2 & -1.674 .560 & $9.863073^{*}$ & 178349.1 & 17.74560 & 18.24347 & 17.84279 \\
3 & -1.643 .747 & 4.005723 & 203513.8 & 17.83747 & 18.53448 & 17.97353 \\
4 & -1.560 .530 & 9.153880 & 142677.8 & 17.40530 & 18.30146 & 17.58024 \\
5 & -1.478 .755 & 7.359715 & $107508.2^{*}$ & $16.98755^{*}$ & $18.08286^{*}$ & $17.20137^{*}$ \\
\hline * indicates lag order selected by the criterion & & & & \\
LR: sequential modified LR test statistic (each test at 5\% level) \\
FPE: Final prediction error \\
AIC: Akaike information criterion \\
SC: Schwarz information criterion
\end{tabular}

Nominanl minimum wage growth rate and COLI growth rate series were found to be stationary on their first differences. Prior to Johansen and Jeselius co-integration tests, optimal lag lenghts were determined. The information criteria results for optimal lag lengths to analyze the relationship between COLI growth rates and nominal minimum wage growth rates are given in Table 8. As seen from Table 8 the optimal lag length for this model was five according to four information criteria.

Table 9: Co-Integration Test Results to Analyze The Relationship Between COLI Growth Rates and Nominal Minimum Wage Growth Rates

\begin{tabular}{|c|c|c|c|c|}
\hline \multicolumn{5}{|c|}{$\begin{array}{l}\text { rowth Rates and Nominal Minimum Wage Growth Rates } \\
\text { Unrestricted Co-Integration Rank Test (Trace) }\end{array}$} \\
\hline & & Trace & 0.05 Critical & \\
\hline No. of CE(s) & Eigenvalue & Statistic & Value & Prob.** \\
\hline None * & 0.864956 & 45.05508 & 15.49471 & 0.0000 \\
\hline At most $1 *$ & 0.308688 & 7.014112 & 3.841466 & 0.0081 \\
\hline \multicolumn{5}{|c|}{$\begin{array}{l}\text { Trace test indicates } 2 \text { co-integrating eqn(s) at the } 0.05 \text { level } \\
{ }^{*} \text { denotes rejection of the hypothesis at the } 0.05 \text { level } \\
{ }^{* *} \text { MacKinnon-Haug-Michelis (1999) p-values }\end{array}$} \\
\hline \multicolumn{5}{|c|}{ Unrestricted Co-Integration Rank Test (Maximum Eigenvalue) } \\
\hline No. of CE(s) & Eigenvalue & $\begin{array}{r}\text { Max-Eigen } \\
\text { Statistic }\end{array}$ & $\begin{array}{r}0.05 \text { Critical } \\
\text { Value }\end{array}$ & Prob.** \\
\hline None * & 0.864956 & 38.04097 & 14.26460 & 0.0000 \\
\hline At most $1^{*}$ & 0.308688 & 7.014112 & 3.841466 & 0.0081 \\
\hline
\end{tabular}


After determining the optimal lag lengths and orders of co-integration, Johansen and Jeselius co-integration tests can be applied. Table 9 shows the results of the co-integration tests for the models respectively. It can be seen that for each model there was a long-run relationship in between variables. The tables also reveal that there were two co-integration equations for our models.

\begin{tabular}{|c|c|c|c|}
\hline \multicolumn{4}{|l|}{ D(INF) } \\
\hline Excluded & Chi-sq & df & Prob \\
\hline D(NWAGE) & 24.84592 & 5 & 0.0001 \\
\hline All & 24.84592 & 5 & 0.0001 \\
\hline \multicolumn{4}{|l|}{ D(NWAGE) } \\
\hline Excluded & Chi-sq & $\mathrm{df}$ & Prob. \\
\hline $\mathrm{D}(\mathrm{INF})$ & 123.4934 & 5 & 0.0000 \\
\hline All & 123.4934 & 5 & 0.0000 \\
\hline
\end{tabular}

VECM based Granger causality relationships between COLI growth rates and nominal minimum wage growth rates were calculated in the last step. It can be concluded from Table 10 that a two way causality was present in between COLI growth rates and nominal minimum wage growth rates.

\subsection{Conclusion and policy implication}

The evaluation of the changes in real minimum wages and hence the relationship between real minimum wage growth rates and real GDP growth rates depend on the type of price deflator selected. In this study we assumed that the Turkish CPI $(1994=100)$ underestimates the changes in the cost of living conditions of the minimum wage earners during 1988-2012 period. Moreover our hypothesis was that if minimum wages were to be deflated by using a different price index - Istanbul Chamber of Commerce's cost of living index (COLI) where the assigned weights of food and housing are higher- rather than the CPI $(1994=100)$ the granger causality outcomes we observed in our earlier study (Sunal and Sezgin Alp, 2015) would have been significantly different. The findings obtained from our analysis were consistent with our expectations. No causality between real minimum wage growth rates and real GDP growth rates (in both directions) were observed in this study. In our previous paper a one way causality (Turkish GDPs $\rightarrow$ Turkish Real Minimum Wages) was prevalent when real minimum wages were deflated by using CPI $(1994=100)$. Besides bidirectional causality between nominal minimum wage growth rates and COLI inflation rates were observed in this study.

In a similar way in line with our expectations official Turkish CPI in this study was found to underestimate the changes in price levels by $33.8 \%$ when compared to a different price index COLI $(1968=199)$ constructed by Istanbul Chamber of Commerce where food expenditures have a substantially higher $(+12,75 \%)$ weight. Therefore when real minimum wages are calculated by using COLI deflators the rise in real wages between 19882012 period is $76 \%$. Though the same ratio is $167 \%$ when official CPI deflators are used. Also Yükseler (2014) revealed in his study by using TUIK's and Eurostat's data that the lowest $20 \%$ income group spent $34.1 \%$ on food in 2013 while the share of food in CPI (2013) was $29.16 \%$. Also the housing expenditures of the same income group were $33.3 \%$ and the share of housing expenditures in CPI (2013) was $16.68 \%$. Also between 2005-2013 period the cumulative rise in general prices according to CPI was 0.88 fold while the rises in food and housing were way higher than that respectively 1.05 fold and 1.19 fold. Therefore there is a strong evidence that The Turkish CPI underestimates especially the cost of living for low income households in Turkey.

We believe that these findings might have some very important policy implications. The miscalculation of changes in prices either as an underestimation or an overestimation of the real cost of living changes poses a major threat for the economy as a whole. Likewise in this manner the accuracy of the calculations have long been argued internationaly as well. In our case when calculated by using COLI deflators the rise in real minimum wage rates are slightly higher than a third of the rise in real GDP growth rates during 1988-2012 period. Moreover no Granger 
causality is present. In that respect asserting that the minimum wage earners took their fair shares from national income growths seems highly doubtful since the determination of minimum wage levels has been a source of debate for a long time in Turkey.

The employers are concerned with higher operational costs in an era of tight competition conditions both domestically and internationally. The governments feel responsible for controlling fast rising highly volatile general price levels as it poses a major threat for the economy as a whole. And on the other hand the welfare and the purchasing power of millions of families in Turkey (41\% of formal workers were receiving minimum wages as of year 2012) depend on minimum wages. Under these tight constraints minimum wage rates are being determined every year. The more important issue is that the minimum wages represent the welfare of more than half of the workforce in Turkey. As of year 2014 according to TÜRK-İS (The largest Trade Union Confederation in Turkey) the minimum wages were $77 \%$ below the poverty line for a typical 4 member household. Moreover at least 4 household members had to be working and bringing minimum wages to the household so as to surpass the poverty threshold in Turkey by year 2014. Therfore, the non-causality and the underestimation findings of this study might have a crucial role in the correction of the negative minimum wage bias. As an important suggestion for the policy makers first of all at least a price index which will reveal the true change in the cost of living of minimum wage dependent households might be used. More specifically an index should be constructed where the CPI basket items and their weights will be determined from the data that will be gathered only from the expenditures of minimum wage dependent households. Moreover rather than an inflation oriented minimum wage determination a welfare driven process might be implemented. Therefore as an alternative policy suggestion a better price deflator should be constructed and the rises in real national income growths and productivity growths should also be reflected directly when determining minimum wages to provide a just and a better distribution.

\section{References}

Barrett, G.F., Brzozowski, M. (2010). "Using Engel Curves to Estimate The Bias in The Australian CPI", The Economic Record, 68 (272), 1-14. http://dx.doi.org/10.1111/j.1475-4932.2009.00594.x

Beatty, K.M., Larsen, E.R. (2005). "Using Engel Curve to Estimate Bias in The Canadian CPI As a Cost of Living Index", Canadian Journal of Economics, 38(2), 482-99. http://dx.doi.org/10.1111/j.00084085.2005.00289.x

Boskin (Chair), M. J., E. R. Dulberger, R. J. Gordon, Z. Griliches, D. W. Jorgenson. 1996. Final report of the Commission to Study the Consumer Price Index. U.S. Senate, Committee on Finance, Washington DC: GPO.

Costa, D.L. (2000). "American Living Standards 1888-1994: Evidence From Consumer Expenditures", NBER Working Papers, No: 7650, 1-29.

Deere, D., Murphy, K. and Welch, F. (1995). "Employment and the 1990-1991 Minimum Wage Hike." American Economic Review, 85(2), 232-37.

Dickens, R., Manning,S. ve Machin, A. (1999). "The Effects of Minimum Wages on Employment: Theory and Evidence from Britain", Journal of Labor Economics,17(1), 1-22. http://dx.doi.org/10.1086/209911

Dickey, D. A., Fuller, W. A. (1979). "Distribution of the Estimators for Autoregressive Time Series with a Unit Root", Journal of the American Statistical Association, 74 (366), 427-431 http://dx.doi.org/10.2307/2286348

Engle, R. F., Granger, C. W. J. (1987). "Cointegration and Error Correction: Representation, Estimation and Testing," Econometrica, 55(2), 251-276. http://dx.doi.org/10.2307/1913236

Granger, C. W. J. (1969). "Investigating Causal Relations by Econometric Models and Cross- Spectral Methods", Econometrica, 37, 424-438. http://dx.doi.org/10.2307/1912791

Hamilton, B.W. (1998). "The True Cost of Living: 1974-1991", J. Hopkins University Working Paper Archive. http://krieger2.jhu.edu/economics/wpcontent/uploads/pdf/papers/wp395Hamilton.pdf (15.04.2015)

Heineke, J.M. (1979). "Exact Aggregation and Estimation", Economics Letters, 4, $157-62$. http://dx.doi.org/10.1016/0165-1765(79)90227-1

Irmen, A. and Wigger, B. (2002). "National Minimum Wages, Capital Mobility and Global Economic Growth," CEPR Discussion Papers 3286..

Johansen, S. and Juselius, K. (1990), "Maximum Likelihood Estimation and Inference on Co-integration With Applications for the Demand for Money", Oxford Bulletin of Economics and Statistics, 52 (2), $169-210$. http://dx.doi.org/10.1111/j.1468-0084.1990.mp52002003.x

Kaufman, B.E. (2010). "Institutional Economics and The Minimum Wage: Broadening The Theoretical and Policy Debate", Industrial and Labor Relations Review, 63(3), http://dx.doi.org/10.1177/001979391006300304

Moosa, I.A. (1997). "Does The Chinese Official CPI Underestimate Inflation?", Applied Economics Letters, 4, 301 4. http://dx.doi.org/10.1080/758532597 
Murphy, E., Garvey, E. (2005). "Cost of Living Indices and Flexible Consumption Behaviour: A Partial Critique", National University of Ireland Working Paper, No:103, 1-13.

Murphy, E., Garvey, E. (2004). "A Consumer Price Index For Low Income Households in Ireland (1989-2001)", Combat Poverty Agency Working Paper Series, No: 04/03, 1-34.

Neumark, D., Wascher, W. (2006). "Minimum Wages and Emplyment:A Review of Evidence from The New Minimum Wage Research", NBER Working Paper Series, Working Paper 12663, Cambridge:USA.

Prasch, E. (1996). "In Defence of The Minimum Wage", Journal of Economic Issues, 30(2), $391-397$. http://dx.doi.org/10.1080/00213624.1996.11505802

Rama, M. (2001). "Teh Consequences of Doubling The Minimum Wage: The Case of Indonesia", Industrial and Labour Relations Review, 54(4), 864-881. http://dx.doi.org/10.2307/2696117

SGK İstatistik Yıllıkları (2012). 5510 Sayılı Kanunun 4-1/a Maddesi Kapsamındaki Zorunlu Sigortalıların ve Prim Ödeme Gün Sayılarının Kazanç Aralıklarına, Sektörlere ve Cinsiyete Göre Dağılımı, http://www.sgk.gov.tr/wps/portal/tr/kurumsal/istatistikler/sgk_istatistik_yilliklari (15.03.2014)

Stigler, G. (1946). "The Economics of Minimum Wage Legislation" American Economic Review, 36(3), $358-65$.

Stigler, G. (1961). The Price Statistics of The Federal Government. New York: National Bureau of Economic Research.

Sunal, O., Sezgin Alp, Ö. (2015). "Türkiye'de Reel Asgari Ücretler ve Reel GSYİH Değişmeleri Arasındaki Nedensellik İlişkisi: Enflasyon Oranına Endekslenmiş Bir Nominal Asgari Ücret Politikası", Ankara Üniversitesi SBF Dergisi, 70(1), 111-29. http://dx.doi.org/10.16987/ausbf.80017

TÜİK Hanehalkı İşgücü Anketi Sonuçları, İstihdam Edilenlerin Yıllara Göre İşteki Durumu, http://www.tuik.gov.tr/PreTablo.do?alt_id=1007 (15.03.2104)

TÜRK-ISŞ Haber Bülteni, Şubat 2014 Açlık ve Yoksulluk Sinırı, http://www.turkis.org.tr/source.cms.docs/turkis.org.tr.ce/docs/file/acliksubat14.pdf (15.03.2014)

Yükseler, Z. (2014). "Türkiye'de Tüketim Harcamalarının Yapısı ve Gıda Harcamaları". http://www.researchgate.net/publication/258808662_YATIRIMTASARRUF_DENGES_TRKYE_UYGULAMAS I. (21.03.2015) 